\title{
VITAMIN A IN DIETS FOR NILE TILAPIA
}

\author{
Daniela Ferraz Bacconi Campeche ${ }^{1 *}$; Rodrigo Ramos Catharino²; Helena Teixeira Godoy²; \\ José Eurico Possebon Cyrino \\ ${ }^{1}$ Embrapa Semi-Árido - BR 428, km 152, C.P. 23 - 56300-970 - Petrolina, PE - Brasil. \\ ${ }^{2}$ UNICAMP/FEA - Depto. de Ciência de Alimentos, R. Monteiro Lobato, 80, C.P. 6121 - 13083-862 - Campinas, \\ $S P$ - Brasil. \\ ${ }^{3}$ USP/ESALQ - Depto. de Zootecnia, Setor de Piscicultura, Av. Pádua Dias, 11 - 13418-900 - Piracicaba , SP - \\ Brasil. \\ *Corresponding author <daniela.campeche@cpatsa.embrapa.br>
}

\begin{abstract}
Dietary vitamin supplementation decrease stress caused by high stocking density, and boosts immunological system of farmed fish. A studied was carried out to determine vitamin A requirements of Nile tilapia (Oreochromis niloticus) in an all male group (13.8 $\pm 1.2 \mathrm{~g}$ ) and a mixed sex population $(9.8 \pm 2.3 \mathrm{~g})$. Fish stocked in 100 -L plastic aquaria $\left(26.0 \pm 1.0^{\circ} \mathrm{C}\right)$ were fed to near satiety, twice a day, seven days a week, during 75 days with vitamin A-free, semi-purified diets supplemented with $0 ; 600 ; 1,200 ; 1,800 ; 2,400 ; 3,000 ; 3,600 ; 4,200 ; 4,800$ and 5,400 International Units (IU) of retinyl palmitate $(30 \%$ vitamin A) per $\mathrm{kg}$ of diet in a completely randomized experimental design, factorial arrangement $2 \chi 10(n=4)$. Deficiency signs of vitamin A were observed in fish fed 0 to 1.200 IU vitamin $\mathrm{A} \mathrm{kg}^{-1}$ diet; moderate signs were observed in fish fed diets with 1.800 to $3.600 \mathrm{IU}$ vitamin $\mathrm{A} \mathrm{kg}^{-1}$ diet; no interactions group*level $(p<0.05)$ were detected. Dietary levels of vitamin A up to $5.400 \mathrm{IU} \mathrm{kg}^{-1}$ influenced final weight and weight gain of fish $(p<0.05)$, but did not influence feed consumption $(p>0.05)$. A group effect was observed regarding all performance variables $(p<0.0001)$. Quantification of hepatic retinol (HPLC) detected vitamin A only in fish fed $5.400 \mathrm{IU}$ retinol kg of diet, therefore characterizing that dietary retinol was used and stored. The quantity of $5.400 \mathrm{IU}$ of retinol kg $\mathrm{of} \mathrm{diet}^{-1}$ is recommended for adequate nutrition of Nile tilapia.
\end{abstract}

Key words: Oreochromis niloticus, retinol, nutrition

\section{VITAMINAAEM DIETAS PARATILÁPIADO NILO}

\begin{abstract}
RESUMO: A suplementação de vitaminas na dieta diminui o estresse e estimula o sistema imunológico causado por altas densidades de estocagem dos peixes. Este trabalho determinou a exigência em vitamina A para a tilápia do Nilo em uma população monosexo masculina (13.8 $\pm 1.2 \mathrm{~g})$ e em uma população original $(9.8 \pm 2.3 \mathrm{~g})$. Os peixes foram estocados em aquários plásticos de $100 \mathrm{~L}(26.0 \pm$ $1.0^{\circ} \mathrm{C}$ ) e alimentados "ad libitum", duas vezes ao dia, sete dias da semana, durante 75 dias com dieta semi-purificada suplementada com $0 ; 600 ; 1.200 ; 1.800 ; 2.400 ; 3.000 ; 3.600 ; 4.200 ; 4.800$ e 5.400 UI de retinyl palmitato ( $30 \%$ de vitamina $\mathrm{A}$ ) por $\mathrm{kg}$ de dieta, em um delineamento experimental totalmente ao acaso e arranjo fatorial $2 \chi 10(n=4)$. Deficiência nutricional severa foi observada em peixes alimentados com 0 a 1.200 UI vitamina $\mathrm{A} \mathrm{kg}^{-1}$ de dieta; sinais moderados foram encontrados em peixes alimentados com 1.800 a 3.600 UI vitamina $\mathrm{A} \mathrm{kg}^{-1}$ de dieta; interações grupo*nível $(p<0,05)$ não foram detectadas. $\mathrm{O}$ aumento de nível de vitamina A influenciou no peso final e no ganho de peso dos peixes $(p<0,05)$, mas não influenciou o consumo de ração $(p>0,05)$. Foi observado efeito de grupo no desempenho dos peixes $(p<0,0001)$. Foi detectado o retinol hepático através de HPLC somente no grupo alimentado com $5.400 \mathrm{UI}$ de retinol kg $\mathrm{kg}^{-1}$ de dieta, caracterizando assim que o mesmo foi utilizado e armazenado. A quantidade de 5.400 IU de retinol $\mathrm{kg}^{-1}$ de dieta é a mínima recomendada para tilápia do Nilo.

Palavras-chave: Oreochromis niloticus, retinol, nutrição
\end{abstract}

\section{INTRODUCTION}

Commercial production of tilapia requires the use of high quality, complete feed. Increasing vitamin supplementation of complete diets decreases stress caused by high stocking density, and boosts immunological system of fish (Davis et al., 1998; Halver, 1985; Toguyeni et al., 1997). On the other hand, in- adequate dietary vitamin supplementation can result in diseases outbreaks or reduced growth in a confined fish population (Hepher, 1988; NRC, 1993; De Silva \& Anderson, 1995; Harikumar et al., 1996; Goswami \& Dutta, 1991; Taveekijaran, 1994; Thompson et al., 1995).

Excess dietary fat-soluble vitamins are stored in hepatic lipid deposits (NRC, 1993; Ornsrud et al., 
2002); $90 \%$ of the stored vitamin $\mathrm{A}$ is found in the liver (Katuyama \& Matsuno, 1988). Therefore, quantifying vitamin A depots in hepatic tissue elicits establishing metabolic and nutritional requirements (Hole \& Taylor, 1996).

Vitamin A requirements were determined for channel catfish (1,000 to 2,000 International Units (IU) kg ${ }^{1}$ of diet), salmonids (2,500 $\mathrm{IU} \mathrm{kg}^{-1}$ of diet), carp (4,000 to $20.000 \mathrm{IU} \mathrm{kg}^{-1}$ of diet), Japanese flounder (10.000 IU $\mathrm{kg}^{-1}$ of diet) and greasy grouper Epinephelus tauvina $\left(3,101 \mathrm{IU} \mathrm{kg}^{-1}\right.$ of diet) (NRC, 1993; Hepher, 1998; Hernandez et al., 2007; Mohamed et al., 2003). Saleh et al. (1995) determined that vita$\min \mathrm{A}$ requirement of Nile tilapia is $5,000 \mathrm{IU} \mathrm{kg}^{-1}$ diet. $\mathrm{Hu}$ et al. (2006) determined that vitamin A requirement of hybrid tilapia $O$. niloticus $\times O$. aureus ranges on 5,850 to $6,970 \mathrm{IU} \mathrm{kg}^{-1}$. This same author also registered that tilapia can utilize $\beta$-carotene to fulfill the dietary vitamin A requirements. However, Kubitza et al. (1998) and Kubitza \& Cyrino (1999) reported that Brazilian commercial feeds for omnivorous, tropical fish may contain from 3,000 to $22,000 \mathrm{IU} \mathrm{kg}^{-1}$ vitamin A. The aim of this study was to verify the use of vitamin $\mathrm{A}$ in diets for Nile tilapia, through the determination of hepatic vitamin A storage capacity and double check discrepant, reported dietary vitamin A requirement of juvenile Nile tilapia fed semi-purified diets, through the evaluation of growth rate and deficiency signs.

\section{MATERIALAND METHODS}

Fish (19 per aquarium) were kept in 40100 -L plastic aquaria, supplied by a closed recirculation system. Aeration was provided continuously throughout the experiment. Water $\mathrm{pH}$, dissolved oxygen (OD) and temperature $\left(26 \pm 1.0^{\circ} \mathrm{C}\right)$ were monitored on a daily basis. Fish were fed for 11 weeks with vitamin A-free, semi-purified diets supplemented with $0,600,1.200$, $1.800,2.400,3.000,3.600,4.200,4.800$ and 5.400 IU of vitamin $\mathrm{A} \mathrm{kg}^{-1}$ diet (Table 1), in a completely randomized experimental design, factorial arrangement $2 \chi 10(\mathrm{n}=4)$. Retinyl palmitate (Rovimix TO 500 Roche $^{\circledR} ; 30 \%$ vitamin A) was used as dietary vitamin A source. The diet was formulated based on albumin and gelatin protein (Table 1). The mixture was extruded through a mincer (ML-4.0 WEG- $\mu$ line); pellets were collected, dried overnight in a forced air oven $\left(55^{\circ} \mathrm{C}\right)$; grinded to $1 \mathrm{~mm}$ pellets, sized, hermetically packed and stored under refrigeration until use. Fish were fed to near satiety twice a day (6:00 am and 6:00 pm).

The trial was duplicated with (i) an all-male, sexreversed Nile tilapia juvenile population (SR), (13.76 $\pm 1.21 \mathrm{~g}$ ), and (ii) a mixed-sex population (NSR) (9.83
Table 1 - Formulation and proximate composition of the experimental diets.

\begin{tabular}{lc}
\hline Ingredients & Contents (\%) \\
\hline Albumin & 32.10 \\
Gelatin & 7.70 \\
Corn starch & 44.13 \\
Soybean oil & 6.00 \\
a - Cellulose & 6.00 \\
Bicalcium Phosphate & 3.00 \\
Vitamin A-free and mineral mix & 0.50 \\
Vitamin C & 0.05 \\
Sodium choride & 0.50 \\
BHT & 0.02 \\
\hline Proximate composition & \\
\hline Dry matter (\%) & 92.09 \\
Gross energy (kcal kg $\left.{ }^{-1}\right)$ & 4791 \\
Crude protein (\%) & 34.70 \\
Crude lipid (\%) & 2.65 \\
\hline Crude fiber (\%) & 3.83 \\
Ash (\%) & 4.79 \\
\hline
\end{tabular}

${ }^{1}$ Units $\mathrm{kg}^{-1}$ of diet: vit $\mathrm{D}_{3} 200,000 \mathrm{UI}$; vit E 12,000 mg; vit. $\mathrm{K}_{3}$ $2,400 \mathrm{mg}$; vit $\mathrm{B}_{1} 4,800 \mathrm{mg}$; vit $\mathrm{B}_{2} 4,800 \mathrm{mg}$; vit $\mathrm{B}_{6} 4,000 \mathrm{mg}$; vit $\mathrm{B}_{12} 4,800 \mathrm{mg}$; folic acid 1,200 mg; pantothenic acid 1,200 mg; vit C 48,000 mg; biotin $48 \mathrm{mg}$; niacin 24,000 mg; Fe $10.000 \mathrm{mg}$; $\mathrm{Cu}$ 600 mg; Mn 4,000 mg; Zn 6,000 mg; I 20 mg; Co 2 mg; Se 20 mg. ${ }^{2}$ Vit C (Lutavit C- Aquastab BASF ${ }^{\circledR}$ ). ${ }^{3} \mathrm{BHT}=$ Butil hidroxi tolueno.

$\pm 2.30 \mathrm{~g})$. Fish were acclimated to the aquaria and fed for fifteen days prior to the beginning of the feeding trials with the non-supplemented diet to simulate or induce deficiency (NRC, 1993).

Apparent signs of vitamin A deficiency - e.g. exophthalmia, depigmentation, clouding of corneal epithelium, anorexia, warped gill operculum, reduced growth, poor feed efficiency, and high mortality (Tacon, 1992) - were recorded through visual observations along the experimental period and at the end of the trial in all fish. The following growth data were recorded at the beginning and ending the experimental period: initial and final weigh; weight gain [(final weigh) - (initial weigh)]; feed consumption; feed conversion ratio [(feed consumption $) \div$ (weight gain)]; and survival rate $[100 \times($ final number of animals $) \div$ (initial number of animals)]. At the end of the trials, hepatic tissue was sampled from fish and stored in liquid nitrogen. High pressure liquid chromatography (HPLC) was utilized to quantify vitamin A in the hepatic tissue lipid depots (Landen-Júnior \& Eitenmiller, 1979).

Data were submitted to ANOVA and regression analysis by the PROC GLM, SAS software (SAS In- 
stitute, 2001), for linear and quadratic effects of the treatments on final weight (FW), weight gain (WG), feed conversion rate (FCR) and survival (S).

\section{RESULTS AND DISCUSSION}

\section{Deficiency signs}

The same clinical deficiency signs were observed for animals of all groups fed vitamin-A deficient diet. Normally colored livers with dark-colored gal bladders, a characteristic sign of clinical stress (Halver, 1989; Roberts, 1981; Post, 1987; Steffens, 1989; Tacon, 1992; Plumb, 1999) was also recorded (Table 2).

Vitamin A deficiency signs in $O$. niloticus include: abnormal swimming behavior; internal hemorrhages; protruded, blind eyes; anemia; hemorrhage in the base of fins and in the skin (Saleh et al., 1995). In advanced deficiency condition Saleh et al. (1991) also observed widespread depigmentation and edemas in the abdomen, sometimes associated with ascites; reduction of mucus secretion and dry, hard mucous tissue. Lesions observed post-mortem appeared as ascites, clubbed gills and hemorrhagic kidneys. Hemorrhagic, amorphous, granulomatous spleen; necrotic, granulomatous, amorphous liver were conspicuously found in the present work in fish receiving less than 1,200 IU vitamin $\mathrm{A} \mathrm{kg}^{-1}$ diet. Spleen severe conditions were also registered to a lesser extent in fish fed diets containing 1,800 2,400 IU vitamin $\mathrm{A} \mathrm{kg}^{-1}$ diet.
Cherry salmon Oncorhynchus massou fed vitamin A-deficient diets for 15 weeks presented clinical signs similar to those described above (Taveekijaran et al., 1994). Similar observations were reported for catfish Heteropneustes fossilis, greasy grouper Epinephelus tauvina, Atlantic halibut Hippoglossus hippoglossus L. and sunshine bass juvenile Morone chrysops $\times M$. saxatilis (Harikumar et al., 1996, Mohamed et al., 2003; Moren et al., 2004; Hemre et al., 2004). The use of advanced juveniles, which may have adequate body reserves of vitamin A, may explain the low incidence of ocular problems, opposing to observations of Poston et al. (1977) with rainbow trout.

\section{Growth parameters}

Weight gain (WG), feed conversion ratio (FCR), survival (S) and feed consumption rate (FCR) data are presented in Table 3. A linear effect $(p<=0.01)$ was detected for FW and FCR, but no effect was detected regarding WG $(p>=0.05)$ (Figure 1 and 2). This may have resulted from differences in fish initial weight. Several research reports are in accord to these results. $\mathrm{Hu}$ et al. (2006) reported that hybrid tilapia fed diets supplemented with 50,000 IU vitamin $\mathrm{A} \mathrm{kg}^{-1}$ present better weight gain $(601 \%)$ and better feed conversion ratio (1.00). Saleh et al. (1995) also observed that Nile tilapia juveniles fed diets supplemented with 5,000 IU vitamin $\mathrm{A} \mathrm{kg}^{-1}$ presented better weight gain $(23.9 \mathrm{~g})$, better feed consumption rate $(60.2 \mathrm{~g})$, and better feed

Table 2 - Percent incidence of clinical signs of vitamin A deficiency recorded in all Nile tilapia juveniles fed diets varying vitamin A levels.

\begin{tabular}{|c|c|c|c|c|c|c|c|c|c|c|c|c|c|c|c|c|c|}
\hline \multirow{2}{*}{ Diet } & \multicolumn{17}{|c|}{ Deficiency signs of vitamin A recorded (\%) } \\
\hline & \multicolumn{2}{|l|}{0} & 600 & \multicolumn{2}{|l|}{1,200} & 1,800 & \multicolumn{2}{|l|}{2,400} & \multicolumn{2}{|l|}{3,000} & \multicolumn{2}{|c|}{3,600} & \multicolumn{2}{|l|}{4,200} & 4,800 & \multicolumn{2}{|c|}{5,400} \\
\hline & & & 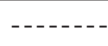 & (n-10 & 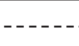 & 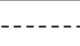 & $-\ldots-$ & $\mathrm{mg} \mathrm{v}$ & vit $\mathrm{A} \mathrm{k}$ & $g^{-1}-\ldots$ & (n-.-- & 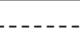 & 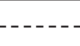 & $-\cdots-1$ & 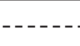 & (1)-- & \\
\hline $\begin{array}{l}\text { Clinical signs during } \\
\text { the experiment } \\
\text { period }\end{array}$ & SR & NSR & SR NS & $\mathrm{R}$ SR & NSR & NSR & $\mathrm{SR}$ & NSR & SR & NSR & SR & NSR & SR & NSR & SR & NSR SR & NSR \\
\hline Pale liver & & 0.13 & 0.1 & & & & 0.52 & & 0.39 & & & & & & & & 0.13 \\
\hline Skin without scale & & 0.13 & & & 0.13 & & & & & & & & & 0.13 & & & \\
\hline Cataract & & & 0.26 & & & 0.13 & & 0.13 & & 0.13 & & & & & & & \\
\hline $\begin{array}{l}\text { Hemorrage lateral } \\
\text { fin }\end{array}$ & & & & & & & & & & & & 0.13 & & & & & \\
\hline Exophtalm & & & & & & & & & & & & & 0.13 & & & & \\
\hline $\begin{array}{l}\text { Clinical signs after } \\
\text { the experiment } \\
\text { period }\end{array}$ & & & & & & & & & & & & & & & & & \\
\hline Ascites & & & & & 0.13 & & & & & 0.13 & & & & & & & \\
\hline $\begin{array}{l}\text { Granulomatous, } \\
\text { necrotic spleen }\end{array}$ & 0.65 & 0.65 & 2.630 .6 & 52.10 & 27 & 1.44 & 1.44 & 0.39 & 0.65 & 0.13 & & 0.13 & & 0.13 & & & \\
\hline $\begin{array}{l}\text { Granulamatous, } \\
\text { amorphous liver }\end{array}$ & 3.94 & 5.00 & 3.943 .9 & 42.10 & 0.65 & & & & & & & 0.13 & & 0.13 & & 0.13 & \\
\hline Amorphous kidney & 2.63 & & 2.633 .9 & 43.94 & & & & & & & & & & & & & \\
\hline
\end{tabular}

$\mathrm{SR}=$ sex-reverted; NSR $=$ non sex-reverted 
Table 3 - Growth performance of the juveniles fed diets varying vitamin A levels.

\begin{tabular}{|c|c|c|c|c|c|}
\hline \multicolumn{6}{|c|}{ Growth performance } \\
\hline Group & IW & FW & WG & $\mathrm{FC}$ & FCR \\
\hline SR & 13.76 & 43.70 & $\begin{array}{r}-\mathrm{g}- \\
29.94\end{array}$ & 33.82 & 1.12 \\
\hline NSR & 9.83 & 27.03 & 17.22 & 25.45 & 1.49 \\
\hline \multicolumn{6}{|c|}{$\begin{array}{l}\text { Vitamin A level } \\
\left(\mathrm{IU} \mathrm{kg} \mathrm{kg}^{-1}\right)\end{array}$} \\
\hline 0 & 11.14 & 31.61 & 20.46 & 32.46 & 1.58 \\
\hline 600 & 10.64 & 30.09 & 19.45 & 29.62 & 1.53 \\
\hline 1200 & 11.94 & 33.29 & 21.35 & 28.83 & 1.38 \\
\hline 1800 & 11.70 & 32.84 & 21.14 & 26.04 & 1.28 \\
\hline 2400 & 12.93 & 36.72 & 23.79 & 28.16 & 1.20 \\
\hline 3000 & 12.73 & 37.24 & 24.51 & 29.10 & 1.20 \\
\hline 3600 & 12.56 & 38.58 & 26.02 & 30.85 & 1.23 \\
\hline 4200 & 10.97 & 37.02 & 26.05 & 29.90 & 1.17 \\
\hline 4800 & 11.74 & 37.49 & 25.75 & 29.34 & 1.16 \\
\hline 5400 & 11.55 & 38.81 & 27.26 & 32.04 & 1.20 \\
\hline
\end{tabular}

$\mathrm{SR}=$ sex-reversed; $\mathrm{NSR}=$ non sex-reversed, $\mathrm{IW}=$ initial weight $\mathrm{FW}=$ final weight $\mathrm{WG}=$ weight gain; $\mathrm{FC}=$ food consumption; $\mathrm{FCR}$ $=$ food conversion rate.

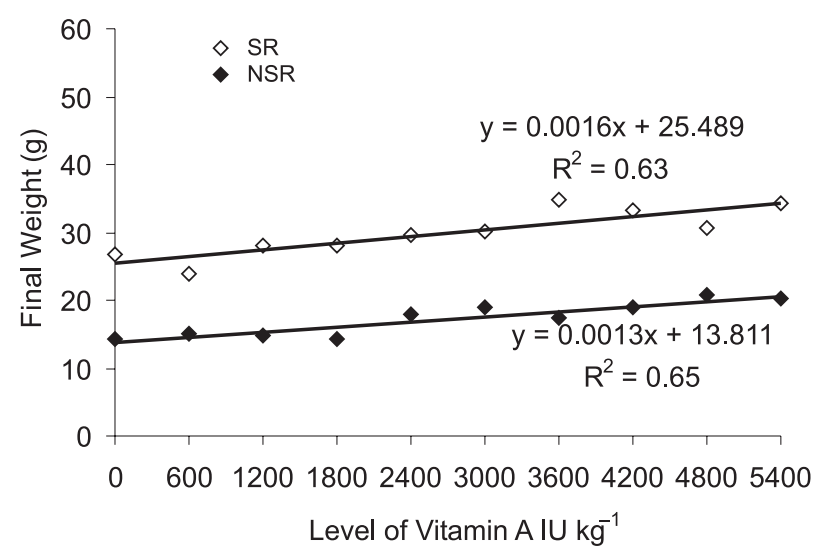

Figure 1 - Final weight (FW) of the animals (SR: sex-reverted; NSR: non sex-reversed) in response to the levels of vitamin A inclusion.

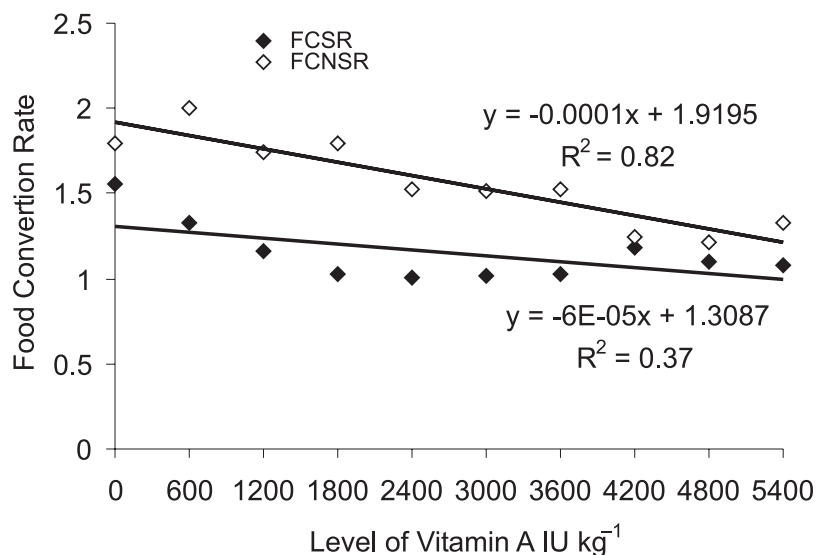

Figure 2 - Food conversion rate (CR) of the animals (FCSR: sexreverted; FCNSR: non sex-reversed in response to the levels of vitamin A inclusion. conversion ratio (2.5), than fish fed diets containing $0,10,000$ or 40,000 IU vitamin $\mathrm{A} \mathrm{kg}^{-1}$. Mohamed et al. (2003) observed that diets supplemented with 3,764 $\mathrm{mg}$ vitamin $\mathrm{A} \mathrm{kg}^{-1}$ for greasy grouper led to a better weight gain $(420.94 \%)$, better feed conversion ratio (1.42) and better protein efficiency ratio (2.08). Sunshine bass fed diets supplemented with 509 - 40,516 $\mu \mathrm{g}$ vit $\mathrm{A} \mathrm{kg}^{-1}$ had no difference in weight gain (269$285 \%)$ or feed efficiency $(0.88-0.89)$ (Hemre et al., 2004). On the other hand, Hernandez et al. (2007) observed that Japanese flounder Paralicthys olivaceous fed fish meal-based diets supplemented with $0.00 \mathrm{IU}$ vitamin $\mathrm{A} \mathrm{kg}^{-1}$ presented better specific growth rate (4.9\%). Also, Atlantic halibut fed diets supplemented with $0-250 \mathrm{mg}$ of retinal $\mathrm{kg}^{-1}$ had no differences in final weight or mortality (Moren et al., 2004).

Survival rate obeyed to a quadratic effect $(p<=$ 0.001) (Figure 3). Saleh et al. (1995) reported that groups of Nile tilapia receiving 5,000 and 10,000 IU vitamin $\mathrm{A} \mathrm{kg}^{-1}$ diet had $93 \%$ survival ratio. Thus increasing dietary vitamin A levels up to $10,000 \mathrm{IU} \mathrm{kg}^{-1}$ do not significantly reduce survival rate of Nile tilapia. Mortality rate of rainbow trout juveniles was not influenced when feeding on either vitamin A-free diet or diets supplemented with 10,000 IU of retinyl palmitate $\mathrm{kg}^{-1}$ for a maximum 20 weeks (Poston et al., 1977). This data for rainbow trout corroborates results for Japanese flounder, greasy grouper, hybrid tilapia, and sunshine bass (Hernandez et al., 2007; Mohamed et al., 2003; Hemre et al., 2004; Hu et al., 2006). 


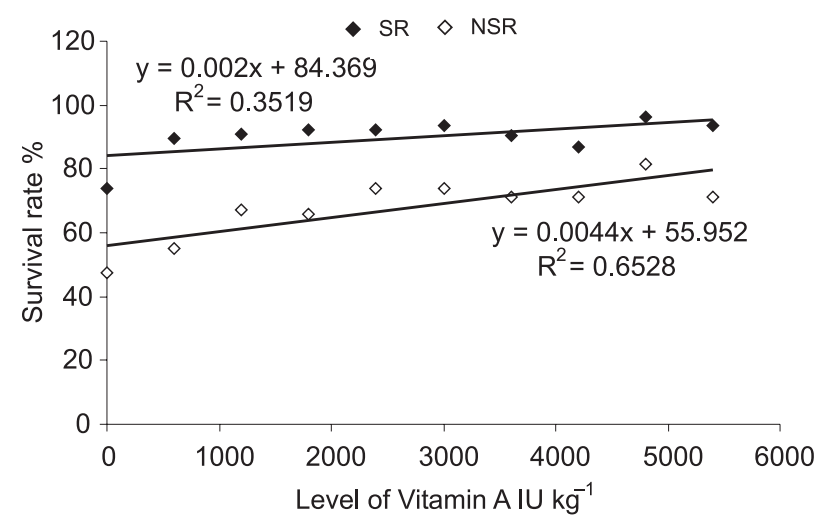

Figure 3 - Survival rate (S) in response to the different levels of vitamin A inclusion (SR: sex-reversed; NSR: non sex-reverted).

Regardless of dietary vitamin A level, sex-reversed fish had better growth rates in comparison to the mixed sex groups. Actually, monosex tilapia populations usually present better growth rates as a result of altered endocrine status induced by populational skewed sex ratio (Toguyeni et al., 1997).

\section{Hepatic retinol}

High performance liquid chromatography (HPLC) analyses did not detect vitamin A in hepatic tissue sampled from fish receiving 0 to 4,800 IU of retinyl palmitate $\mathrm{kg}^{-1}$ diet. The detectable level was of $45 \pm$ $10 \mathrm{mg}$ of vitamin A $100 \mathrm{~g}^{-1}$ hepatic tissue. Only fish receiving the $5,400 \mathrm{IU} \mathrm{kg}^{-1}$ presented detectable amounts $-136 \pm 10 \mathrm{mg}$ of vitamin A $100 \mathrm{~g}^{-1}$ hepatic tissue. Therefore only this level of dietary vitamin A supplementation exceeded fish metabolic requirements and so, only after meeting the metabolic needs of the animals, it could be stored in the liver. Fontagné et al. (2006) fed Siberian sturgeon Acipenser baeri larvae with vitamin A and also found retinal palmitate as the main storage form of vitamin A with $6.7 \mu \mathrm{g} \mathrm{g}^{-1}$ in larvae fed diets with the highest vitamin A level, that was $772,500 \mathrm{IU} \mathrm{kg}^{-1}$.

Camargo et al. (1975) determined concentrations of retinol $\left(\mathrm{mg} \mathrm{g}^{-1}\right)$ and other compounds derived from vitamin A in hepatic lipid depots of six neotropical, fresh water fish captured in the Moji-Guaçu river, State of Sao Paulo, Brazil: curimbatá Prochilodus scrofa 3.32; dourado Salminus maxillosus 7.62; piapara Leporinus piapara 4.30; mandiuva Pimelodus clarias 2.85; piava Leporinus copelandi 3.40. Hole \& Taylor (1996) reported that the dogfish Squalus acanthias concentrate as little as $0.047 \mathrm{mg} \mathrm{g}^{-1}$ retinol in the liver. Hernandez et al. (2007) also did not detect retinol in livers of Japanese flounder fed fish meal-based diet not supplemented with vitamin A, and the level of retinol in the fish liver increased respectively, in the diets supplemented with 10,000 IU vitamin $\mathrm{A} \mathrm{kg}^{-1}$ and 25,000 IU vitamin $\mathrm{A} \mathrm{kg}^{-1}$ respectively. Hemre et al. (2004) reported for sunshine bass fed diets supplemented with 0-509 $\mu \mathrm{g}$ of retinyl acetate $\mathrm{kg}^{-1}$, the level detected by HPLC where over $924 \mu \mathrm{g}$ of retinyl acetate $\mathrm{kg}^{-1}$ was supplemented in the diet. Vitamin A retention was not significant in hybrid tilapia fed diets supplemented with levels below 6,000 IU vitamin $\mathrm{A} \mathrm{kg}^{-1}$ when detected by HPLC (Hu et al., 2006).

In exception to the dourado, all other fish studied by Camargo et al. (1975) had plant material as major food items; this same feeding behavior is true for Nile tilapia (Lowe-McConnel, 1975; Beveridge \& McAndrew, 2000). Rodriguez-Amaya (1999) reported that the concentration of $\beta$-carotene, a conspicuous pro-vitamin A in plant tissue tops $360 \mathrm{IU} \mathrm{g}^{-1}$; actually, any plant tissue which contains $46 \sim 74 \mathrm{IU} \mathrm{g}^{-1} \beta$-carotene is considered a concentrated source of vitamin A. In exception to the control (no supplementation), any other tested level within the scope of this work (600 5,400 IU of vitamin $\mathrm{A} \mathrm{kg}^{-1}$ of the diet) lies within the high to the mega-dose of dietary vitamin A supplementation. Therefore, the amount of hepatic retinol detected in this study meets any assumed expectation, and the fact that the highest dietary vitamin A contents $-5,400 \mathrm{IU} \mathrm{kg}^{-1}$ - elicited best growth performance do not surprise either.

\section{ACKNOWLEDGEMENTS}

Authors are indebted to Fundação de Amparo à Pesquisa do Estado de São Paulo (FAPESP- Sao Paulo State Research Foundation) for the financial support to this research project in the form of the MSc scholarship to DFBC.

\section{REFERENCES}

BEVERIDGE, M.C.M.; McANDREW, B.J. Tilapias: biology and exploitation (Fish and Fisheries Series, 25). London: Kluwer Academic, 2000. 505p.

CAMARGO, L.A.A.; YASHUDA, Y.; SAAD, W.A. Vitamina A em óleo de fígado de peixes brasileiros de água doce. Archivos Latinoamericano de Nutrición, v.25, p 273-281, 1975.

DAVIS, K.B.; SIMCO, W.A.; LI, M.; ROBINSON, E. Effect of reduction of supplementary dietary vitamins on the stress response of channel catfish Ictalurus punctatus. Journal of the World Aquaculture Society, v.29, p.319-324, 1998.

DE SILVA, S.S.; ANDERSON, T.A. Fish nutrition in aquaculture. London: Chapman \& Hall, 1995. 319p.

FONTAGNÉ, S.; BAZIN, D.; BREQUE, J.; VACHOT, C.; BERNARDE, C.; ROUAULT, T.; BERGOT, P. Effects of dietary oxidized lipid and vitamin A on the early development and antioxidant status of Siberian sturgeon (Acipenser baeri) larvae. Aquaculture, v.257, p.400-411, 2006.

GOSWAMI, U.C.; DUTTA, N.K. Vitamin A-deficient diet and its effects on certain haematological parameters of Heteropneustes fossilis a 3-4 dehydroretinol rich freswater fish. International Journal of Vitamin Nutrition Research, v.61, p.205-209, 1991. 
HALVER, J.E., Recent advances in vitamin nutrition and metabolism in fish. In: COWEY, C.B.; MACKIE, A.M.; BELL, J.G. Nutrition and feeding in fish. London: Academic Press, 1985. p.415429.

HALVER, J.E., The vitamins. In: HALVER, J.E. Fish nutrition. 2 ed. San Diego. Academic Press, 1989. p.32-109.

HARIKUMAR, P.; KARATI, R.; GOSWAMI, U.C. Vitamin Adeficiency and its effects on the lysosomal enzymes of fish. International Journal of Vitamin Nutrition Research, v.66, p.97-100, 1996.

HEMRE, G.I.; DENG, D.F.; WILSON, R.P.; BERNTSSEN, M.H.G.. Vitamin A metabolism and earlier biological responses in juvenile sunshine bass (Morone chrysops x M. saxatilis) fed graded levels of vitamin A. Aquaculture, v.235, p.645-658, 2004.

HEPHER, B., Nutrition of pond fishes. Cambridge: Cambridge University Press, 1988. 388p.

HERNANDEZ, L.H.H.; TECHIMA, S.; KOSHIO, S.; ISHIKAWA, M.; TANAKA, Y.; ALAM, M.S. Effects of vitamin A on growth, serum anti-bacterial activity and transaminase activities in the juvenile Japanese flounder, Paralichtys olivaceus. Aquaculture, v.262, p.444-450, 2007.

HOLE, S.M.; TAYLOR, K.D.A. Methods of extraction composition and stability of vitamin A and other components in dogfish (Squalus acanthias) liver oil. Food Chemestry, v.55, p.215220, 1996.

HU, C.J.; CHEN, S.M.; PAN, C.H.; HUANG, C.H. Effects of dietary vitamin $\mathrm{A}$ or $\beta$-carotene concentrations on growth of juvenile hybrid tilapia, Oreochromis niloticus x O. aureus. Aquaculture, v.253, p.602-607, 2006.

KATUYAMA, M.; MATSUNO, T. Carotenoid and vitamin A, and metabolism of carotenoids, $\beta$-carotene, canthaxanthin, astaxanthin, zeaxanthin, lutein and tunaxanthin, lutein and tunaxanthin in tilapia Tilapia nilotica. Comparative Biochemistry and Physiology. v.90B, p.131-139, 1988.

KUBITZA, F.; CYRINO, J.E.P. The effects of feed quality and feeding practices on the quality of fish: a Brazilian fish culture outlook. In: CHANG, Y.K.; WANG, S.S. (Ed.) Advances in extrusion technology. Lancaster: Technomic, 1999. 171 p.

KUBITZA, F.; CYRINO, J.E.P.; ONO, E.A. Rações comerciais para peixes no Brasil: situação atual e perspectivas. Panorama da Aqüicultura. v.8, p.38-49, 1998.

LANDEN JÚNIOR., W.O.; EITENMILLER, R.R. Appliccation of gel permeation chromatography and nonaqueous reverse phase chromatography to high pressure liquid chromatographic determination of retinyl palmitate and $\beta$-carotene in oil and margarine. Journal of the AOAC International, v.62, p.283289, 1979.

LOWE-McCONNEL, R.H., Fish communities in tropical freshwaters. London: Longman, 1975. 337p.

MOHAMED, J.S.; SIVARAM, V.; ROY, T.S.C.; MARIAM, M.P.; MURUGADASS, S.; HUSSAIN, M.F. Dietary vitamin A requirement of juvenile greasy grouper (Epinephelus tauvina). Aquaculture, v.219, p.693-701, 2003.
MOREN, M.; OPSTAD, I.; BERNTSSEN, M.H.G.; INFANTE, J.L.Z.; HAMRE,K. An optimum level of vitamin A supplements for Atlantic halibout (Hippoglossus hippoglossus, L.) juveniles. Aquaculture, v.235, p.587-599, 2004.

NATIONAL RESEARCH COUNCIAL - NRC. Nutrient requirements of fish. Washington, D.C.: National Academy Press, 1993. 114p.

ORNSRUD, R; GRAFF, I.E.; HOIE, S; TOTLAND, G..K.; HEMRE, G..I. Hypervitaminosis A in first-feeding fry of the Atlantic salmon (Salmo salar, L.). Aquaculture nutrition. v.8, p.7$13,2002$.

PLUMB, J.A. Health maintenance and principal microbial diseases of cultured fishes. Ames: Iowa State University Press, 1999, 328p.

POST, G. Textbook of fish health. Neptune City: T.F.H. Publications, 1987, 288p.

POSTON, H.A.; RIIS, R.C.; RUMSEY, G.L.; KETOLA, H.G. The effect of supplemental dietary amino acids, minerals and vitamins on salmonids fed cataractogenic diets. Cornell Veterinary, v.67, p.472-509, 1977.

ROBERTS, R.J. Patologia de los peces. Madrid: Mundi-Prensa, 1981. 355p

RODRIGUEZ-AMAYA, D.B. Carotenoides y preparación de alimentos: la retención de los carotenoides provitamina A en alimentos preparados, procesados y almacenados. Washington, D.C.: USAID/JSI, 1999. 105 p. (OMNI Project).

SALEH, G.; ELERAKU, W.; GROPP, J.M. A short note on the effects of vitamin A hypervitaminosis on health and growth of Tilapia nilotica (Oreochromis niloticus ). Journal of Applied Ichthyology, v. 11, p.382-385, 1995

SAS INSTITUTE. SAS/STAT user's guide: statistics v.8.2. Cary: SAS Institute, 2001

STEFFENS, W. Principles of fish nutrition. New York: Haslted Press, 1989. 384p.

TACON, A.G.J. Nutritional fish pathology. Rome: FAO, 1992. 75p. (FAO Fisheries Technical Paper, 330)

TAVEEKIJARAN, P.; MIYAZAKI, T.; MATSUMOTO, M.; ARAI, $\mathrm{S}$. Vitamin A deficiency in cherry salmon. Journal of aquatic animal health, v.6, p.251-259, 1994.

THOMPSON, I.; CHOUBER, C.; HOULIHAN, D.F.; SECOMBES, C.J. The effect of dietary vitamin A and astaxanthin on the immunocompetence of rainbow trout. Aquaculture, v.133, p.91-102, 1995

TOGUYENI, A.; FAUCONNEAU, B.; BOUJARD, T.; FOSTIER, A.; KUHN, E.R.; MOL, K.A.; BAROILLER, J.F. Feeding behavior and food utilization in tilapia, Oreochromis niloticus: effect of sex ratio and relationship with the endocrine status. Physiology Behaviour, v.62, p.273-279, 1997.

Received December 17, 2007

Accepted May 28, 2009 